\title{
Simplicidade e singularidade: arte "virgem" na concepção de Mário Pedrosa
}

\author{
Simplicity and singularity: \\ 'virgin' art according to Mário Pedrosa's conception
}

\author{
Giovana Caires Motta ${ }^{1}$; Marta Dantas ${ }^{2}$
}

\begin{abstract}
Resumo
No início do século XX, a expressão artística de pacientes de hospitais psiquiátricos passou a ser alvo de interesse e estudo. Na década de 40, Mário Pedrosa, um importante crítico de arte brasileiro, analisou a produção plástica de um grupo de pacientes do Centro Psiquiátrico Pedro II e defendeu o valor estético da mesma. O objetivo desta pesquisa, portanto, é analisar a visão de Mário Pedrosa frente a essas produções, bem como as teorias e conceitos que contribuíram para a sua concepção de arte "virgem", sem perdermos de vista o contexto histórico favorável à legitimação dessas produções.
\end{abstract}

Palavras-chave: Mário Pedrosa. Arte "virgem". Criação. Arte/loucura.

\begin{abstract}
In the beginning of the $20^{\text {th }}$ Century, asylums patients' artistic expressions started to be valued and studied. In the 1940's, Mário Pedrosa, an important Brazilian art reviewer, analyzed a group of patients' work from Centro Psiquiátrico Pedro II and defended its aesthetic value. This work, thus, aims to analyze Mário Pedrosa's point of view towards the patients' work as well as the theories and concepts that helped to construct his idea of 'virgin' art, considering the favorable historical context to the validation of such work.
\end{abstract}

Key words: Mário Pedrosa. 'Virgin’ art. Creation. Art/insanity.

1 Graduada em Educação Artística pela Universidade Estadual de Londrina. E-mail: gicmotta@yahoo.com.br.

2 Professora Doutora do Departamento de Arte Visual e do Programa de Pós-Graduação em Letras da Universidade Estadual de Londrina. 


\section{Introdução}

$\mathrm{O}$ crescimento das pesquisas enfocando a vinculação entre arte, psicologia e psiquiatria é observável desde o final do século XIX. Contudo, é no século XX que encontramos modificações nos conceitos científicos, artísticos e estéticos. Estudos referentes à expressão artística de doentes mentais, à investigação psicológica da mesma e ao conceito de criação passaram a ser valorizados. Os psiquiatras e historiadores da arte, como, por exemplo, Marcel Réja e Hans Prinzhorn, trouxeram importantes contribuições para esses estudos. No Brasil, o contato com essas pesquisas proporcionou um crescente interesse acerca das relações entre arte e loucura. Esse interesse iniciou-se, em São Paulo, na década de 20, com o psiquiatra Osório César, que, em 1929, publicou o livro $A$ Expressão Artística dos Alienados, contendo uma análise das produções de pacientes do Hospital do Juqueri. Esta obra teve grande relevância no debate sobre a arte dos alienados no Brasil.

Um fator que contribuiu para a integração entre as áreas social, médica e educacional, estaria relacionado ao Movimento de Higiene Mental, o qual se voltava para as preocupações com a saúde psíquica. Como essa idéia estendeu-se, rapidamente, por vários países, outras propostas semelhantes foram surgindo. As décadas de 20 a 40 foram marcadas por transformações não só no contexto cultural, mas, também, no social e político. O modernismo literário e artístico estabelecia-se e a expressão plástica dos esquizofrênicos mostravase em sintonia com os ideais estéticos modernistas. Frente a todas essas questões, a presente pesquisa restringe-se ao pensamento de um importante crítico de arte brasileiro, Mário Pedrosa, com a sua concepção de arte "virgem".

A psiquiatra Nise da Silveira, na década de 40, organizou, juntamente com o artista plástico Almir Mavigner, uma oficina de arte no Centro Psiquiátrico Pedro II, no Rio de Janeiro, que mais tarde deu origem ao Museu de Imagens do Inconsciente. $\mathrm{O}$ acervo de obras deste museu foi construído a partir da produção plástica de um grupo de pacientes que freqüentavam as oficinas de Terapêutica Ocupacional. A primeira exposição dos trabalhos dos internos data de 1950 e provocou grande polêmica.

Mário Pedrosa, diante dos trabalhos dos pacientes da Dra. Nise, defendeu o valor estético dos mesmos e mostrou-se contrário ao preconceito referente à expressão plástica dos alienados. Essa expressão, que não é estruturada por regras préestabelecidas, nem ordenada pela tradição clássica, foi denominada, por Pedrosa, de arte "virgem", na medida em que é realizada por criadores que, espontaneamente, começam a pintar depois de adultos. Cabe lembrar a sintonia e a simultaneidade entre o debate provocado por Mário Pedrosa e aquele provocado por Jean Dubuffet, na França. Este último denominava essa produção não polida, de arte "bruta". O questionamento sobre a idéia de arte psicopatológica foi instaurado, mas como a patologia, para Dubuffet, não interfere no valor artístico da produção, essa idéia passou a ser combatida.

Mário Pedrosa concentrou parte de seu trabalho crítico na obra de alguns pacientes do Centro Psiquiátrico Pedro II, tais como: Carlos, Emygdio, Adelina, Raphael, Isaac e Fernando. A posição crítica de Pedrosa, frente à produção plástica dos alienados, envolve conceitos e teorias que, de alguma maneira, contribuíram para a sua concepção de arte "virgem". Podemos destacar a Teoria da Gestalt, a Teoria da Evolução de Darwin, o fenômeno do "primitivismo" e a visão "romântica" de criação e gênio orgânico. Em um contexto favorável à valorização de formas puras, "brutas" e "simples", mostraremos como foi possível a legitimação das produções plásticas dos doentes mentais.

Tendo em vista a insuficiência de pesquisas que abordem o debate sobre a relação entre arte e loucura, no Brasil, este trabalho justifica-se e pretende dar a sua contribuição. Por fim, esclareceremos 
que tudo está intimamente ligado: o conceito de criação, a teoria da forma, o pensamento referente à idéia de simplicidade e de espontaneidade; todos eles conciliados no discurso de Mário Pedrosa, diante da expressão plástica dos artistas, como ele próprio designou, "virgens". Para ele, essas produções constituem, em si, verdadeiras obras de arte. A imagem que Pedrosa tinha dessa produção "virgem" encontrava-se, portanto, em sintonia com as pesquisas da época.

\section{Primitivismo e primitivo}

\section{Neocolonialismo e etnologia}

É necessário lembrar que os estudos sobre as sociedades tribais iniciaram-se no século XIX, no contexto do neocolonialismo. A expansão colonial estendeu-se por diversos territórios e possibilitou o descobrimento de novas civilizações e de suas respectivas culturas. Em virtude do processo de industrialização, a Europa passa a necessitar de algumas matérias-primas que não existem em seu território, precisando, desse modo, explorar novas áreas. Com isso, observava-se, na Europa, uma corrida colonial, visando à África e à Ásia. O fator principal era o econômico - busca de matéria-prima e mercados consumidores - porém, encontrava-se, também, uma necessidade de dar vazão ao crescimento populacional. O mundo não se restringia mais ao ocidente, novos territórios foram desvendados. Assim, o neocolonialismo proporcionou não só a revelação e a exploração de áreas como: Ásia, África e Oceania, mas, também, o contato com novas culturas.

Os arqueólogos e os empreendimentos de caráter cultural, geográfico e antropológico acompanharam essa expansão e isso possibilitou o reconhecimento de outras culturas. As expedições na África e na Oceania revelaram aos europeus uma produção artística altamente criativa. A arte deixou de se restringir às elites intelectuais e passou a ser produto, também, das sociedades "primitivas" (PEDROSA, apud ARANTES, 1996). Portanto, a população ocidental, em larga medida, passou a se interessar por esses povos "primitivos" e a valorizar as suas produções plásticas.

No debate acerca da constituição do termo "primitivo", encontramos dois percursos: a sua definição em termos negativos, mas, também, como um valor positivo. Assim, ao mesmo tempo em que a palavra designou culturas e povos inferiores e atrasados, surgiu uma concepção positiva das sociedades mais simples e com pensamentos e expressões mais puros (PERRY, 1998). Quando nos referimos ao termo "primitivo" como um valor negativo, precisamos apontar alguns elementos que contribuíram para a formação desse pensamento. Sob a influência da Teoria da Evolução de Darwin, surge a idéia de que as formas mais "simples", ou ainda, "primitivas", não teriam evoluído. Uma outra abordagem importante refere-se à corrente filosófica positivista, do século XIX, a qual tinha como precursor Auguste Comte. O positivismo compreendia a evolução como um fenômeno natural de toda a matéria. Assim, estendendo o conceito de evolução das ciências naturais para toda a realidade, estruturou-se a idéia de progresso no positivismo. A partir do século XIX, observa-se a idéia de evolução inter-relacionada à de progresso.

Diante das questões de evolução e progresso, além da concepção de que as formas mais rudimentares seriam consideradas inferiores, o etnólogo Lucien Lévy-Bruhl, no começo do século XX, acreditava que as civilizações tribais encontravam-se em um estado "primitivo", considerando-as, portanto, como inferiores às sociedades civilizadas. A partir desse pré-conceito, evidencia-se, no pensamento de LévyBruhl, a determinação da diferença e da partilha. Para ele, a mentalidade "primitiva" era regida por representações coletivas, místicas, e não obedecia exclusivamente às leis da lógica ocidental, sendo denominada como pré-lógica; não no sentido de constituir uma etapa anterior do pensamento lógico, mas de não percorrer todos os princípios da lógica e da racionalidade ocidentais (CAZENEUVE, 
1963). A mentalidade "primitiva", para o etnólogo, mostrava-se diferente do dualismo ocidental. Para entender melhor essa questão, é preciso analisar, inicialmente, como foi formada a noção de dualismo ocidental. Com isso, faz-se necessário recorrer ao filósofo Descartes (1996), o qual acreditava em duas certezas - a existência de um indivíduo, enquanto ser pensante, e a existência de uma matéria, isto é, o mundo físico e o pensamento humano. Frente a esses fatores, estrutura-se o dualismo cartesiano - distinção entre corpo e alma. No entanto, essa separação, segundo Lévy-Bruhl, não fazia parte da mentalidade "primitiva". Assim, a dualidade "primitiva" se ordenaria em termos de totalidade. Dessa maneira, realiza-se a diferença entre dualidade na concepção dos povos "primitivos" e o dualismo ocidental. Por fim, é perceptível que algumas características, que se referem à noção de progresso e de racionalidade, acabaram, de uma maneira ou de outra, influenciando a análise de Lévy-Bruhl sobre a sociedade "primitiva", a partir de um ponto de vista baseado em termos de inferioridade.

Contrário a essas idéias, na segunda metade do século XX, o antropólogo Lévi-Strauss colocava, no mesmo nível, os povos civilizados e as sociedades "primitivas", sem, portanto, inferiorizálas. O "selvagem", para ele, não era mais atrasado ou inferior ao civilizado. Contudo, antes do antropólogo defender essas idéias, o fenômeno do "primitivismo" já tinha se ocupado dessa valorização do "primitivo". Em Pensamento Selvagem, de 1970, Lévi-Strauss afirma que este não se refere ao modo de pensar dos selvagens, mas ao pensamento em estado selvagem, isto é, sem domesticação. Dentro da questão acerca de uma mentalidade prélógica, Lévi-Strauss comentava que o "pensamento selvagem" seria lógico, desenvolvendo-se pelo percurso do entendimento e não da afetividade, como pensava Lévy-Bruhl.

Através das pesquisas de Lévy-Bruhl e de Lévi-Strauss, observamos que, por caminhos um pouco divergentes, ambos contribuíram para a definição do termo "primitivo", seja de maneira negativa ou positiva. Assim, neste último, nota-se uma preocupação em romper com pré-conceitos estabelecidos, frente às sociedades "primitivas", ao passo que, em Lévy-Bruhl, encontra-se um julgamento superficial, permeado por uma idéia pré-concebida de inferioridade, influência tanto do darwinismo, quanto do positivismo.

\section{Fenômeno do primitivismo}

Podemos dizer que o emprego do termo "primitivo" foi utilizado, desde o século XIX, para diferenciar as sociedades européias de outras definidas como menos civilizadas. Assim, encontrase, nas civilizações ocidentais, uma crença na sua superioridade em relação à realidade "primitiva". Para o público em geral, que se baseia em préconceitos culturais e na valorização dos padrões clássicos, o "primitivo" é considerado inferior e definido de maneira negativa.

No século XIX, o termo "primitivo" era usado para se referir à arte pré-renascentista, à arte persa, peruana e outras, entretanto, a partir da primeira metade do século XX, o seu uso ficou mais restrito, passando a designar a arte e a cultura da África e da Oceania. Ao se utilizar "primitivo" no lugar de uma denominação geográfica da cultura em questão, consequentemente, essa cultura estaria sendo classificada como diferente, ou seja, "primitiva", a partir da noção ocidental do que é civilizado. Utilizar esse termo é fazer um juízo de valor (PERRY, 1998).

A idéia de inferioridade, atribuída ao "primitivo", foi questionada pelo "primitivismo". O "primitivismo" constituiu-se como fenômeno, pois ele não representa uma escola, um estilo ou um grupo de artistas formados para estabelecer as bases ou diretrizes de um movimento. Esse termo referese ao interesse dos artistas modernos ocidentais, pela cultura e pela arte das comunidades "primitivas". Esse interesse estruturou-se a partir da sintonia das pesquisas modernistas com as produções 
"primitivas". Ainda que fosse atribuído um valor negativo ao termo "primitivo", no campo da arte, sempre vai prevalecer uma definição positiva.

Diante do termo "primitivo", alguns artistas, do final do século XIX, atribuíram a ele um valor positivo. $\mathrm{O}$ artista francês Paul Gauguin, por exemplo, diante do crescimento industrial e da consolidação de um sistema econômico monopolista, passou a questionar alguns valores perdidos pela sociedade européia, como: o sonho, a fantasia, a religião. Para ele, a cultura européia era decadente e, diante de tal crise, foi buscar, em outros lugares, a pureza e a simplicidade de pessoas que não tinham sido corrompidas pelo progresso. Em uma carta, de 1890, Gauguin escreveu:

Possa eu um dia (e talvez brevemente) refugiar-me nas florestas de uma ilha da Oceania, e lá viver de êxtase, de calma e de arte. Cercado de uma nova família, longe dessa luta européia pelo dinheiro. No Taiti poderei, no silêncio das belas noites tropicais, escutar a doce música murmurante dos movimentos de meu coração em harmonia amorosa com seres misteriosos que me cercam. Livre, enfim, sem preocupações com dinheiro, poderei amar, cantar e morrer (CHIPP, 1996, p. 75)

Isso comprova não só o seu interesse pela arte e pela cultura das sociedades "primitivas", mas, também, o seu desejo de refugiar-se em um lugar mais puro, onde pudesse apreender a essência das coisas e reencontrar um tempo perdido. Os mesmos princípios e valores que regiam a vida do artista, também regiam a sua obra; sua ética e sua estética caminhavam juntas. O desvio das regras naturalistas e a simplicidade caracterizam a sua linguagem pictórica. Gauguin acreditava que, ao perder toda a selvageria, os artistas não teriam mais imaginação e força para criar; o selvagem, segundo ele, seria, decididamente, melhor do que nós (CHIPP, 1996).

As máscaras e a estatuária negra, estruturadas por formas simples, que se distanciavam dos padrões clássicos, encontraram, entre os artistas modernos, um rápido reconhecimento, devido à similaridade de ideais estéticos presentes na época. Todavia, é importante ressaltar que o motivo real do interesse desses artistas pela escultura "primitiva", da África e da Oceania, não se restringia ao exotismo do assunto ou do tema, mas as qualidades formais, as linhas e as superfícies. Não podemos esquecer que Matisse interessou-se pela escultura negra, adquirindo, em 1906, algumas estatuetas. Modigliani, Dèrain, Wlaminck, Braque, Picasso e Lhote começaram a cercar-se de objetos de arte negra. Assim, observamos que foi grande o interesse despertado pelos objetos artísticos africanos.

Os surrealistas, empenhados nas pesquisas sobre o inconsciente, juntamente com o seu projeto para que os indivíduos alcançassem a liberdade, mostraram-se, também, interessados pela arte e pela cultura "primitiva", e colecionaram máscaras e estatuetas das sociedades não-ocidentais. Entretanto, não foi simplesmente um interesse plástico-formal, como o de Matisse, Picasso e de outros artistas do início do século XX, pois o "primitivo" os atraía em sua totalidade.

O interesse dos artistas modernos pela produção plástica dos povos "primitivos" e das crianças referia-se a uma valorização da matéria "bruta" e das formas simples. Os modernistas, ao se apresentarem ao público, encontraram, de maneira geral, resistência e desprezo, sendo equiparados, de forma pejorativa, aos loucos e aos "selvagens". A indiferença do público frente a todos esses trabalhos era bem perceptível. No entanto, podemos dizer que um novo conceito de arte foi se estruturando, de maneira que, cada vez mais, os cânones clássicos foram se dispersando, restando espaço, apenas, para uma expressão plástica mais pura e com maior liberdade.

Devido à "ingenuidade" e à "simplicidade", foram encontradas semelhanças entre as produções dos povos "primitivos" e as das crianças. O poeta e teórico da arte Charles Baudelaire já concebia a criança como artista. Segundo ele, a criança vê tudo 
como novidade, até os elementos mais conhecidos não escapam ao seu interesse, e, continua afirmando, que "nada se parece tanto com o que chamamos inspiração quanto a alegria com que a criança absorve a forma e a cor" (BAUDELAIRE, 1988, p. 168). Assim, parece que Baudelaire acreditava na existência de uma capacidade de encantamento das crianças diante das coisas. A sensibilidade, para ele, ocuparia, na criança, um grande espaço. Com Baudelaire, as idéias de espontaneidade e de pureza se fazem presentes no "gênio da infância". Por meio desses elementos, mostrou-se possível estabelecer uma aproximação entre a expressão criativa das crianças e a dos "primitivos".

Na década de 40, em Arte, necessidade vital ${ }^{3}$, o crítico de arte brasileiro, Mário Pedrosa, comenta que o grande público não sabe reconhecer o essencial de um fenômeno artístico, interessando-se apenas pela obra realizada, ou seja, pelo produto final. Assim se concretizaria, segundo o crítico, a incompreensão da arte moderna e da produção plástica de pacientes de hospitais psiquiátricos. Ressalta ainda: "a arte para eles ainda não perdeu a maiúscula. Ainda é uma atividade à parte, excepcional, e o artista um ser misterioso envolto num halo místico ou mágico" (apud ARANTES, 1996, p. 42). Com isso, observamos que o público, de maneira geral, continuava preso aos cânones clássicos e valorizava simplesmente o resultado da obra e não o processo.

Mário Pedrosa, ainda em Arte, necessidade vital, afirma que, para as crianças, para os doentes mentais ou para qualquer indivíduo que é envolvido pela inocência, as formas de arte que impõem menor esforço consciente e intelectual são as mais acessíveis (apud ARANTES, 1996). Essas produções não seriam condicionadas pelas regras da tradição, nem seriam ordenadas por padrões realistas, mostrariam, portanto, formas puras e singulares.

Assim, quandosetratadotermo“primitivo", vários

Conferência pronunciada no encerramento da exposição de pintura, organizada pelo Centro Psiquiátrico Pedro II, em 31.03.1947. são os fatores envolvidos para que a sua definição se concretize. Como vimos, o neocolonialismo foi um processo que possibilitou, através da expansão a outros territórios, o descobrimento de novas sociedades e culturas. Porém, só o contato com a arte e com a cultura desses povos, denominados como "primitivos", não seria suficiente para que essas manifestações tivessem o seu valor reconhecido. Foi o interesse das sociedades ocidentais pelas formas puras e simples que possibilitou o reconhecimento e a valorização dessas produções. $\mathrm{O}$ que os europeus estavam buscando, foi encontrado entre os povos "primitivos". Dentro dessa realidade, acrescida de algumas pesquisas antropológicas acerca das sociedades "primitivas", uma visão positiva do termo foi se estruturando.

Contudo, não se deve esquecer que a racionalidade e as teorias evolucionistas e positivistas contribuíram para que o "primitivo" fosse inferiorizado e definido em termos pejorativos. Dessa forma, é notória a existência de dois caminhos para a definição do termo "primitivo"; um ordenado como uma característica positiva e outro, como um elemento negativo.

Cabe lembrar a importância deste contexto do "primitivismo" e do "primitivo", para a valorização das obras que se distanciavam do academicismo e que se mostravam mais espontâneas. Com isso, ao longo do tempo, os críticos, os artistas e, por vezes, até o próprio público começaram a convergir seus interesses a essas produções artísticas. Os trabalhos plásticos dos doentes mentais também passaram a ser legitimados e essas criações, que não se restringem às regras clássicas e apresentam formas puras, passaram a ser reconhecidas e consideradas como altamente criativas.

\section{Forma e criação}

Teoria em voga na época: teoria da Gestalt

Apsicologia do século XIX dedicava-se à pesquisa da percepção humana, e tinha como base a análise 
atomista, pela qual tentava compreender o conjunto, através de seus elementos. Cada componente era analisado separadamente e o resultado era apenas a experiência da soma ou da acumulação destes componentes. Wilhelm Wundt ${ }^{4}$ seguia esse princípio atomista e reconhecia, em sua doutrina, a idéia de que o todo era distinto de suas partes. Com a fragilidade e a insuficiência dos métodos de análise fundamentados em noções de elemento e associações, surgiu, na Alemanha, no início do século XX, a teoria da Gestalt, também conhecida como Psicologia da Forma. Essa teoria introduz o conhecimento de estrutura ou de forma na explicação do mundo físico, mental e biológico, em que a lei do todo determina suas partes. Wolfgang Köhler, um dos fundadores da Gestalt, não compartilhava das idéias de Wundt e não aceitava o pensamento de que os fatos psicológicos eram formados por átomos inertes sem relação entre si e de que as associações eram um dos únicos elementos responsáveis por suas ordenações (SCHULTZ, 1981). Com isso, ele e outros psicólogos da Gestalt declaravam que a percepção não deveria ser compreendida apenas como um agrupamento de elementos sensoriais, nem como simples soma das partes; a percepção é uma totalidade e a sua organização é espontânea.

Foi na década de 20 que Mário Pedrosa, então graduando do curso de filosofia da Universidade de Berlim, teve, pela primeira vez, contato com essa teoria. Pierre Naville era seu colega, com quem dialogava sobre o problema da forma. Entretanto, só vinte anos mais tarde, ele retomará os estudos da psicologia da forma. Em sua tese, baseada nos teóricos Köhler, Koffka, Paul Guillaume e Wertheimer, Pedrosa tentou utilizar, de maneira sistemática, os ensinamentos gestálticos para solucionar problemas estéticos. Sua intenção não era apenas aplicar os esquemas da Gestalt às obras, mas debater os próprios fundamentos da teoria para a compreensão da criação artística.

Determinado a buscar a pureza artística em

\footnotetext{
4 Médico, filósofo e psicólogo Alemão, fundador da nova ciência da psicologia.
}

expressões mais arcaicas, Pedrosa (1979) propunha conciliar os impulsos inconscientes com os impulsos de ordenação formal. Acreditava que a expressão mais rudimentar já possuiria uma estrutura e que a ordenação, sendo instintiva e exigência do próprio inconsciente, seria como um elemento que iria ao encontro das leis da Gestalt. No combate entre formas possíveis, o agrupamento ou a disjunção realizam-se no sentido de forma privilegiada, ou seja, simétrica, regular e simples. Sendo assim, a lei da "boa forma" estaria presente nos processos primários. Como a capacidade intrínseca da percepção primitiva organiza-se, estruturalmente, da melhor maneira possível, Kurt Koffka ${ }^{5}$ designava essa percepção como artística e, desse modo, a arte fundamentar-se-ia nos princípios da pregnância da forma. $\mathrm{O}$ ato de perceber é um ato de criação e a percepção segue, na simplicidade da organização, às leis da "boa forma" que dirigem a obra de arte e o mundo.

O ser humano está envolvido por formas - seus atos, ordenações, associações - e nenhuma matéria é desprovida de forma. Toda teoria parte de dados que considera como base essencial de sua estrutura e a Gestalt parte da forma como elemento primordial. Nas leis estruturais, os elementos semelhantes e próximos tendem a se unir, tornando possível a realização espontânea da ordenação da percepção. A similaridade pode ocorrer na textura, na cor do objeto, ou ainda na própria sensação do elemento. A percepção tende à simetria e ao equilíbrio. Só existe percepção do objeto se houver diferenças de intensidade; uma pequena diferença de tonalidade entre figura e fundo já é suficiente para que ela se estabeleça. Figura e fundo distinguem-se por suas características funcionais, isto é, ambos possuem sua unidade, porém, existem dois tipos de unidades: a que assume função de figura, possuindo forma e organização, e a que assume a função de fundo, mostrando-se como uma continuidade indefinida, inorgânica (GUILLAUME, 1966). A Teoria da

\footnotetext{
5 Psicólogo Alemão, um dos fundadores da Teoria da Gestalt.
} 
Forma explica a percepção do espaço pelas leis da ordenação. A Gestalt influenciou várias áreas da psicologia, abrangendo, por exemplo, a percepção, a aprendizagem e o pensamento.

De acordo com a teoria da Gestalt, criar corresponderia a formar. $\mathrm{O}$ ato criador abrangeria a capacidade de compreender e, com isso, de ordenar, de relacionar, de configurar e de significar. É na procura de significados e ordenações que o estímulo humano de criar se originaria, ou seja, na tentativa de compreender a vida, o homem seria impulsionado a formar (OSTROWER, 1987).

O psiquiatra e historiador da arte alemão, Hans Prinzhorn, discute os processos criativos ao analisar os mecanismos de ordenação que se evidenciam na produção de pacientes de hospitais psiquiátricos. Na tentativa de explicar como surgiria o impulso criador e a maneira como se realizaria a produção artística humana, Prinzhorn baseavase em uma investigação psicológica derivada da Gestalt (FERRAZ, 1998). Só se vivencia a natureza intrínseca de um objeto ou de uma obra, quando ela é encarada, exclusivamente, como forma. Os fundamentos psíquicos de fenômenos formais concretizar-se-iam na necessidade de expressão presente no ser humano.

É importante lembrar que, segundo essa teoria, quando se trata de um conjunto estruturado, é necessário ter conhecimento das partes através do todo, pois os conjuntos possuem leis próprias e estas regem seus elementos. É através da percepção da totalidade que o cérebro poderia perceber e assimilar um conceito ou uma imagem. A forma sempre será entendida como uma estrutura de relações, como se ordenam e se configuram.

Conhecendo a influência dos princípios da Gestalt e do pensamento de Hans Prinzohrn na estruturação do modo de pensar de Mário Pedrosa, observa-se a busca deste crítico, dentro do plano da forma, como um caminho possível para a compreensão da criação artística. Para ele, os artistas "virgens", por viverem livres das regras acadêmicas, estariam, consequentemente, aptos a manifestar formas de origem inconsciente, mas que corresponderiam a valores estéticos objetivos. O fenômeno artístico dos esquizofrênicos era considerado, por ele, como natural e justificado pela teoria da Gestalt.

\section{Teoria da evolução de Darwin: Criação/ "Primitivo"}

Evolução e criação

Nos discursos sobre "criação" e sobre o significado do termo criar - causar existência, formar, originar-se, nascer - afirma-se que a evolução é naturalmente criativa. No processo evolutivo, criam-se novos sistemas de vida para conquistar os nichos ecológicos disponíveis. A criação é a apresentação de uma nova concepção e uma representação artística (GADAMER, 1977). Nessa perspectiva, são destacadas as semelhanças entre a produção artística e o processo evolutivo. A evolução, em sua contínua manifestação de formas, mostra-se sempre disposta a criar, operando de duas maneiras gerais: por diversificação de populações, gerando outras populações diferentes, sendo que cada uma assume um percurso evolutivo diferente; e pela diferenciação de uma mesma população, a qual, com o tempo, vai se tornando diversa (FREIRE-MAIA, 1988). Os descendentes apresentam diferenciações entre si, pois a evolução não se realizaria se todas as gerações fossem iguais.

Segundo a teoria evolucionista, todos os seres vivos originam-se de organismos muito simples. A grande diversidade dos seres atuais seria o resultado de um longo processo de evolução biológica, fato que se realizaria desde o surgimento da vida. No século XIX, o naturalista Charles Darwin estruturou a idéia de que a evolução era determinada pela seleção natural, a qual privilegiaria os indivíduos que teriam maior probabilidade de sobrevivência e de reprodução, a cada geração, mostrando características pontuais que estariam relacionadas com a adaptação ao ambiente (AMABIS, 1999). Não só no confronto da natureza inanimada 
com outro organismo à procura de uma melhor adaptação, mas também no confronto de outros seres vivos, os inimigos naturais, ordenar-se-ia à luta pela sobrevivência. Assim, diante das condições ambientais nas quais estariam inseridas, as formas que sobreviveriam seriam as que se mostrassem mais aptas.

Sobre a questão da "luta pela sobrevivência", salientam-se as idéias de Thomas Malthus, que traçava um paralelo entre as populações e os meios de subsistência, e terminava por demonstrar que a primeira teria um poder de crescimento muito maior que a última. Pensando nesse desequilíbrio e na continuidade dos seres mais aptos, Darwin, influenciado por Malthus, aplicou essa idéia a todos os seres vivos e, assim, estruturou o conceito de seleção natural.

É na seleção natural, ou em outros processos genéticos que envolvem as populações vivas, que se manifestaria a criatividade da evolução e não no campo da mutação (GADAMER, 1977). Os seres inanimados originam-se por meio de reações mútuas dentro de compostos diversos e, ao produzirem sempre as mesmas características, não poderiam ser classificados como criativos; diferentemente da matéria orgânica, que seria fundamentalmente criadora, porque sempre estaria originando novos elementos. O processo de criação é justificado pelo processo da origem das espécies na natureza. Assim, como conseqüência da teoria da evolução de Darwin, a criatividade é tida como uma força inerente à vida.

\section{Evolução e a idéia de "primitivo"}

A evolução é considerada um processo de continuidade que vai da matéria, tal como ela é encontrada na natureza, até o ser humano. Desde a Antigüidade, já se procurava nos seres rudimentares uma seqüência de aperfeiçoamentos que se encerraria com o homem, o ser considerado mais prefeito (GADAMER, 1977). Ao refletirmos sobre o próprio sentido da palavra evolução, como um processo que consiste na passagem de formas inferiores de organismos vivos para outras mais complexas, ou ainda, no desenvolvimento progressivo de um conjunto de elementos, observamos um pré-conceito diante das formas mais simples e rudimentares - consideradas como inferiores e imperfeitas transpostas a um patamar menos avançado dentro da escala evolutiva. Não se pode perder de vista que as formas mais primitivas possuem suas próprias estruturas, leis e qualidades intrínsecas. Um fator que deve ser lembrado é que, no século XIX, o termo evolução era identificado como melhoria e progresso, reforçando a idéia da valorização dos elementos mais complexos e "evoluídos" como melhores e superiores. Contudo, no século seguinte, os pesquisadores recusaram essa limitada definição do termo.

Todos os seres vivos descendem de uma pura e primitiva forma de vida. Assim, é importante o entendimento do processo evolutivo para a compreensão da vida. De acordo com Mário Pedrosa, as formas plásticas dos doentes mentais poderiam ser analisadas através do pensamento "primitivo", que, quanto mais simples, mais próximo está do início da vida, porque a arte se realizaria pelos mesmos princípios da criação do universo e de seu funcionamento. Não tendo a pretensão de imitar, a arte não copiaria a natureza, porém, seguiria as regras da mesma, transpondo-nos à categoria da criação consciente, humana (PEDROSA, apud ARANTES, 1996). Com isso, é perceptível a influência da teoria da evolução de Darwin, tanto no conceito do "primitivo" quanto no processo de criação artístico.

\section{Teorias}

Dentro do contexto das teorias em voga no século XX e da ressonância da teoria evolucionista de Darwin, com a publicação da Origem das espécies, em 1859, instaura-se um diálogo entre evolução, forma e criação. A evolução, em sua constante revelação de formas, mostrar-se-ia sempre envolvida em um contínuo processo de criação. Por este ponto 
de vista, criar e formar são dois termos que se apresentam sempre de maneira relacionada. Só se estabelece um contato com os elementos intrínsecos à matéria, quando estes são enfrentados unicamente como forma. Tendemos a aproximar os seres que são semelhantes, porque se originariam de um ancestral comum e, nesta circunstância, podemos observar uma sintonia com os princípios da forma, no sentido em que os elementos semelhantes também tendem a se aproximar e a se unir. Darwin observou que a flora e fauna de continentes próximos eram parecidas e em cada lugar havia adaptações específicas, dando origem a diferentes espécies (AMABIS, 1999). Os elementos, sendo agrupados pela semelhança e pela distância em que se encontram, revelam uma outra lei estrutural da forma: a da proximidade. Assim, observamos a presença da semelhança e da proximidade, na estruturação de conceitos e teorias.

Ao pensarmos que os seres vivos derivam de uma simples estrutura de vida, entram em discussão duas questões: o pensamento primitivo e a lei da pregnância da forma. As estruturas mais simples estariam mais perto do início da vida. Por mais rudimentar, toda expressão possuiria uma estrutura. Na área da percepção, existem as formas privilegiadas: regulares, simétricas e simples, as quais são impostas a todos os seres humanos. Permeada pela simplicidade da organização, a percepção estrutura-se da melhor maneira: lei da "boa forma". Através dessas comparações, notamos um acordo mútuo entre os princípios da teoria da Gestalt e as particularidades das idéias propostas por Charles Darwin.

\section{A legitimação da expressão plástica dos alienados: Mário Pedrosa e arte "virgem"}

Um pouco sobre Mário Pedrosa

Mário Pedrosa (1980-1981), um grande intelectual de nossa História, foi integrante de uma família pernambucana culta, estudou na Suíça no período entre 1913 e 1916, e graduou-se no curso de Direito em 1923, no Rio de Janeiro. Nessa época, interessou-se pelas questões sociais e pelo marxismo. Ainda na década de 20, freqüentou os cursos de Filosofia e Sociologia na Universidade de Berlim.

Inicialmente, interessou-se pela política, mas estendeu as suas convicções à arte. Arte e política são termos indissociáveis dentro de sua trajetória. Em sua trajetória política de esquerda, envolveu-se com Partido Comunista Brasileiro (PCB), porém, em 1929, rompeu com este, numa tentativa de reestruturá-lo. Não podemos esquecer que, no final da década de 20, as suas constantes viagens à Europa possibilitaram-lhe o contanto com os surrealistas e intensificaram o seu desejo de luta. De volta ao Brasil, em 1929, Pedrosa continuou lutando contra o sistema capitalista.

O contato com as posições de Trotski ${ }^{6}$ permitiu a formação de um grupo trotskista no Brasil, do qual Pedrosa foi militante político até 1940. Mário Pedrosa foi membro, representante da América Latina, do Comitê Executivo da IV Internacional ${ }^{7}$. Era responsabilidade da IV Internacional, dirigir a classe operária russa em direção a uma revolução social.

Posteriormente, MárioPedrosa, comopseudônimo de Lebrun, envia uma carta a Trotski, comentando sobre a sua insatisfação com o funcionamento da IV Internacional. Esse desentendimento com Trotski repercutiu na exclusão de Pedrosa dessa organização.

Sem abandonar a militância política, Pedrosa começa, gradativamente, a assumir o campo da crítica de arte. Enveredou por esse caminho, a partir de 1933, com a conferência sobre a gravurista Kaethe Kollwitz. Em 1934, um ano após esta conferência, o crítico escreve um estudo sobre a obra de Portinari e retoma à questão social da arte. Um fato importante,

\footnotetext{
6 Trotski foi um intelectual marxista que liderou, juntamente com Lênin, a Revolução de outubro de 1917, na Rússia.

7 IV Internacional foi uma organização fundada em 1938, que teve como principal representante Leon Trotski.
} 
que permitiu uma análise aprofundada das obras de Portinari, foi o refúgio de Pedrosa, devido a perseguições na Praça da Sé, em uma galeria, na qual acontecia uma exposição desse artista.

Convém lembrar que o crítico nunca separou a Revolução Social e a Arte de Vanguarda. A sintonia entre o seu projeto político e o seu pensamento acerca da arte permiti-nos compreender melhor a sua defesa em relação à autonomia da arte. A autonomia, seja ela em relação ao sistema capitalista ou ao academicismo, possibilitaria a tão almejada revolução. Com essas idéias, observamos a total adesão de Pedrosa à arte moderna. Sempre enfatizando uma arte independente, Pedrosa irá afirmar: "A independência da arte - para a revolução: a revolução para a libertação definitiva da arte" (apud ARANTES, 1991, p. 2).

Na década de 40, Mário Pedrosa escreveu um estudo acerca do artista americano, Alexander Calder. Segundo o crítico, Calder "brinca com a modernidade", pois os objetos que este criava eram, na sua visão, elementos da indústria moderna transformados pela fantasia. Com isso, percebemos o interesse de Pedrosa por este artista, devido à sua capacidade criadora frente às questões da indústria e da tecnologia.

Ainda nessa mesma época, Pedrosa envolvese com a crítica referente à expressão plástica dos pacientes do Centro Psiquiátrico Pedro II. Defendendo o valor estético de tais produções e assumindo uma postura semelhante à do artista plástico Jean Dubuffet, Pedrosa passa a questionar a idéia de uma arte psicopatológica.

A crítica de arte, Otília Arantes (1991), afirma que Pedrosa, sem construir uma teoria finalizada da arte, ia reunindo algumas questões teóricas que possibilitavam pensá-la em seu conjunto. Isso é perceptível quando analisamos toda a trajetória de Pedrosa e percebemos que a sua crítica está fundamentada em diferentes teorias que possibilitam explicar a dimensão vital da arte. Conforme a necessidade, Pedrosa ia integrando novas teorias e relativizando outras. É o que faz com a teoria da Gestalt e com as questões referentes à fenomenologia. Embora nunca tenha construído uma crítica completa à Gestalt, ele passou a adotar a fenomenologia para pensar o problema da arte.

Não podemos esquecer que Mário Pedrosa teve, também, um papel relevante nos debates acerca da arquitetura brasileira. Este via a Arquitetura Moderna como uma "síntese das artes", a qual seria projetada, posteriormente, em Brasília. O próprio título de um Congresso, "Brasília, síntese das artes", em 1959, que reuniu críticos para as discussões acerca da construção dessa "nova cidade", foi proposto por Pedrosa. Na década de 60, foi diretor do Museu de Arte Moderna de São Paulo e curador da Bienal de 61.

Mário Pedrosa passou a chamar de pós-moderna a arte contemporânea. Na década de 70, começamos a perceber a descrença de Pedrosa frente à arte, pois estava-se, segundo ele, dentro de um sistema que era contra arte. A revolução, em larga medida, havia fracassado; a vitória devia-se, portanto, ao mercado e às tecnologias eletrônicas. Para o crítico, na Arte Pop americana não existiriam artistas e sim manipuladores da produção de massa (apud ARANTES, 1995). A arte não havia chegado ao fim, pois para Pedrosa, esta não acaba, é permanente; o que estava acontecendo era à cristalização de um mundo em crise. Segundo Pedrosa:

Hoje [1980] a arte não irradia mais influência, não desperta mais atenção [...]. Estamos numa época de crise profunda. De crise ainda mais aguda no Terceiro Mundo [...]. Diante de conflitos tão radicais, terríveis, insolúveis, é natural que a arte passe para um nível secundário (PEDROSA, 1995, p. 32).

Com essas questões, tornam-se visíveis as incertezas diante dos rumos que a arte estava tomando. Neste momento, Mário Pedrosa concentra, novamente, a sua atenção nos problemas políticos. Como resposta ao sistema ditatorial, era preciso que 
o povo oprimido se organizasse para lutar contra tal regime. A classe operária precisava de um partido próprio. A construção de um partido que surgisse dos próprios trabalhadores, mostrou-se como uma solução para o Brasil. Assim, através da necessidade da criação de um partido, formaliza-se, então, a estruturação do Partido dos Trabalhadores (PT). A liderança do movimento operário estava figurada em Luís Inácio Lula da Silva.

Mário Pedrosa, envolvido com os assuntos referentes à classe operária, engajou-se na luta pelo Partido dos Trabalhadores, pois via, neste partido, uma esperança para o país; os trabalhadores, naquele momento, traziam novas perspectivas para o Brasil.

Ao falar sobre o futuro do país, Pedrosa, afirma, em um livro intitulado Sobre o PT que a revolução deveria sair "da bandeira do Partido dos Trabalhadores”. A situação política do Brasil clamava por novas ações. Sendo assim, Pedrosa (1980) continua afirmando que o PT atenderia a todas as regiões do Brasil desprezadas pelo poder Central e traria o futuro para o povo brasileiro.

Ao defender o PT, Pedrosa coloca-se, novamente, em oposição ao autoritarismo do sistema político vigente, mostrando-se favorável à revolução. Nessa linha de pensamento, o crítico afirmava, em 1981:

Ser revolucionário é a profissão natural de um intelectual [...]. Sempre achei que a revolução é a atividade mais profunda de todas [...]. Sempre sonhei uma revolução para o Brasil. [...] A situação é dramática, e eu, um intelectual, não posso fazer nada. Sofro dramaticamente por isso. [...] A saída é fazer a revolução (apud LOUREIRO, 2001, p.132).

Assim, durante toda a trajetória de Mário Pedrosa, é possível observar a simultaneidade entre a sua militância política e a crítica de arte. Mesmo sendo, várias vezes, perseguido politicamente, Pedrosa nunca abandonou os seus ideais. As suas diversas viagens para a Europa e para os Estados
Unidos permitiram o contato com diferentes artistas e intelectuais. Sempre preocupado com as questões referentes à autonomia e à liberdade do indivíduo, ele vai percorrendo toda a sua perspectiva histórica. Portanto, é natural que Pedrosa defenda uma produção artística marginal, que se distancia de normas e regras pré-estabelecidas. A sua fundamental importância no panorama nacional e internacional é inquestionável.

\section{Concepção de "arte virgem" de Mário Pedrosa}

Mário Pedrosa, um dos maiores críticos de arte brasileiros, defendia a política e a arte como formas de manifestação humana. Ele buscava um fundamento para a arte nas necessidades vitais do homem e na própria natureza. A essa expressão, que ele acreditava ter origem nas necessidades vitais do homem, denominou "arte virgem", por não seguir regras pré-estabelecidas e por ser realizada por criadores espontâneos, "virgens", que começam a pintar depois de adultos. A crença na pureza da expressão desses artistas, isentos de convenções acadêmicas, reforça a idéia da utilização do termo "virgem" por Pedrosa.

O contato com a psiquiatra Nise da Silveira, seguidora das teorias de Carl Jung, influenciou o crítico no que se refere ao inconsciente e à penetração em mundo interior. A imagem não seria apenas uma cópia psíquica do mundo externo, mas uma representação das forças inconscientes. Jung usava o termo psiquê para se referir à mente e assim definiu a sua estruturação, comum a todos os indivíduos, através das vivências sociais. Ele ordenou a psiquê através de três níveis: consciente, inconsciente pessoal e coletivo. O inconsciente coletivo, segundo Jung, através de seu caráter universal, poderia ser explicado pela teoria da evolução, devido à similaridade de estruturas cerebrais encontradas em todos os seres humanos (SCHULTZ, 1981). Ainda de acordo com Jung, haveria dois tipos de imagens do inconsciente: as imagens que representam conteúdos do inconsciente pessoal (experiências do 
próprio indivíduo) e imagens de aspecto impessoal, ligadas intimamente às estruturas mais profundas da psiquê, denominadas então, de inconsciente coletivo.

A penetração no mundo interno possibilitou a descoberta de disposições inatas, herdadas para a configuração de imagens e pensamentos semelhantes em todos os lugares e gerações, definidos como os arquétipos. Jung descrevia quatro arquétipos que eram mais recorrentes e que poderiam fazer referência a mitos antigos: anima/animus, sombra, persona e self (SCHULTZ, 1981). O arquétipo da sombra tem um lado positivo (a espontaneidade, a criatividade) e um lado negativo (a parte mais escura e primitiva da personalidade). Segundo o dicionário de símbolos (2001), o termo sombra aparece também dividido em duas partes: o que se oporia à luz e o que seria a imagem dos elementos não-reais. A persona seria o aspecto mais exterior da personalidade; o self proporcionaria estabilidade à personalidade e o anima/animus seria a tendência dos indivíduos em reter as características comportamentais do outro sexo. Jung e seus seguidores acreditavam que esses elementos, em larga medida, estariam representados nas obras dos esquizofrênicos. As imagens arquetípicas produziriam os temas míticos e os símbolos que exprimem as experiências da humanidade.

Nise da Silveira (2001) acreditava que cada indivíduo, esquizofrênico ou não, possui suas particularidades, mas todos têm contato com as força "brutas", inconscientes. O que importava, para ela, era o indivíduo dar forma, ainda que rudimentar, ao que a palavra não podia exprimir. A psicologia analítica tenta descobrir, nas produções plásticas, elementos reprimidos disfarçados, com o objetivo de conduzi-los à consciência. Assim, a imagem é apenas o ponto primordial para então se alcançar os conteúdos inconscientes reprimidos.

Os artistas "virgens", por não estarem presos a modelos pré-concebidos e por não terem a pretensão de copiar o mundo real, estariam mais aptos a manifestar formas vitais e inconscientes. Em Arte, necessidade vital, Mário Pedrosa comenta sobre a descoberta do inconsciente e declara: "No mundo das artes, pela primeira vez, se começa a ter condições para abordar o problema preliminar mas fundamental das suas origens psíquicas, o mecanismo subjetivo dessa atividade antes da obra realizada" (PEDROSA, apud ARANTES, 1996). Com isso, observamos a subjetividade como um fator valorizado nas produções plásticas que se distanciavam dos cânones clássicos e se mostravam mais espontâneas. Nesta perspectiva, o curador geral da XVI Bienal de São Paulo, Walter Zanini, no texto que abre o catálogo Arte Incomum ${ }^{8}$, afirma: "os doentes mentais ou indivíduos desatados dos contextos normais de visualidade, sabem fluir da lógica de seus mundos inconscientes uma grande força libertária" (1981, p. 7). Ainda nesse catálogo, o curador internacional da mesma Bienal, Victor Musgrave, fala que os outsiders ${ }^{9}$ pareciam ter penetrado na região mais profunda e misteriosa da imaginação, onde cada um apresentaria suas particularidades. Para ambos os curadores, a produção plástica do sujeito criador seria permeada pelo inconsciente e pela subjetividade.

Segundo Mário Pedrosa (1947), o artista é entendido não pela sua formação acadêmica, nem pela etnia ou grupo social a que pertence. A atividade artística, para ele, estende-se por toda a humanidade, independente dos elementos culturais estabelecidos em cada cultura ou contexto social; o impulso criador seria uma característica de todo e qualquer indivíduo.

Pedrosa (1979) acreditava que a manifestação de um conteúdo era oriunda de um impulso interior que convidaria o ser humano a se afirmar; esses impulsos afirmativos apareceriam nas manifestações mais simples, mas, aos poucos, iam se perdendo na sociedade mecanizada. Nas crianças, para o crítico,

\footnotetext{
8 Arte Incomum é entendida, por Walter Zanini, como manifestação individual da espontaneidade, sem se reduzir aos princípios culturais estabelecidos.

9 O termo não se refere a nenhuma escola ou movimento.
} 
esses impulsos seriam bem perceptíveis, porém, entre os adultos, eles não encontrariam muito espaço, porque a realidade interior destes estava dominada pelos mecanismos externos. De acordo com ele, a união entre os impulsos de afirmação e os de ornamentação proporcionaria a capacidade de ação sobre o mundo exterior. Esses dois impulsos são entendidos como veículos da necessidade de expressão e classificados como origens primeiras da forma. A manifestação expressiva formaliza-se, assim, através da relação entre o elemento psíquico e o formal. Nestas circunstâncias, novamente entra em discussão a teoria da Gestalt.

O crítico fala, também, de uma "natureza fundamental", ao equiparar as produções dos doentes mentais com as das crianças e dos adultos tidos como normais, por seguirem os mesmos processos psíquicos na criação (ARANTES, 1996). A necessidade básica de expressão seria a exteriorização dos conteúdos psíquicos, contudo, nem toda expressão do inconsciente é tida como arte.

Por fim, Pedrosa defendia a produção de sujeitos criadores espontâneos, puros, "virgens", e valorizava a simplicidade e a singularidade de suas produções, as quais não levavam em consideração quaisquer convenções clássicas ou conceitos estabelecidos. Assim, estrutura-se a concepção do crítico de "arte virgem".

\section{Normalidade e anormalidade psíquica}

Pode-se dizer que os conceitos de normal e patológico são relativos. Michel Foucault acreditava que a doença mental só tinha realidade dentro de uma cultura que a reconhecia como tal (FRAYZEPEREIRA, 1982). Sendo assim, é a sociedade que dita as regras e as normas de comportamento e de pensamento; o que é considerado normal dentro de um contexto, em um outro pode ser definido como patológico. Independente do conteúdo cultural, a loucura é concebida como uma inadaptação do indivíduo ao seu meio e como um desvio comportamental frente às normas estabelecidas.

Quando entra em questão a definição de loucura, várias denominações aparecem: perda da consciência de existência, degenerescência do ser humano, indistinção entre realidade e devaneio, conhecimento da verdade. Enfim, independente da definição, mais favorável ou mais pejorativa, do termo, o sujeito, ao ser compreendido como louco, na maioria das vezes, é marginalizado.

A loucura é um conceito puramente relacional. O homem sempre utilizará um parâmetro de comparação, com isso, será em relação a uma ordem que o conceito vai se definir, por exemplo: é diante dos termos "normalidade" e saúde que a loucura se apresenta como "anormalidade" e doença; sendo assim, os termos normalidade-anormalidade sempre serão apresentados de forma relacionada.

Entre as civilizações mais antigas e os povos primitivos, a loucura era concebida como uma manifestação divina, inspirada pelos deuses como forma de expressão do sagrado. Neste contexto, a loucura tinha um significado sobrenatural e o louco era reconhecido e aceito como diferente, sendo considerado quase como um xamã. Os devaneios e as improvisações dos indivíduos "iluminados" não eram considerados como uma perturbação mental.

O filósofo Sócrates acreditava que os poetas escreviam através de uma condição de gênio e inspiração, classificando-os como videntes ou capazes de adivinhar. As ações dos poetas realizavam-se por meio de uma iluminação inconsciente e divina. Em sua concepção, a loucura era um presente vindo do céu e esta, por ter uma origem divina, consequentemente, estaria acima da mente saudável, que era simplesmente de origem humana (PEDROSA, 1979).

O Renascimento trouxe algumas modificações nos contextos culturais, sociais, econômicos e religiosos. Ao se pensar que, nesse período, o homem e a razão passaram a ser valorizados, em oposição ao sobrenatural e ao divino, elementos presentes no imaginário medieval, a loucura entra em outro 
contexto; não seria mais concebida como uma manifestação divina. No século XVIII, começaram a aparecer os primeiros asilos — instituições reservadas aos loucos — onde o comportamento do alienado era sempre observado diante de uma "conduta normal", sendo que qualquer desvio dessa regra deveria ser seguido de punição. Assim, as anomalias mentais passaram a ser objeto de cuidados médicos e a loucura entrou em conflito com a normalidade das condutas.

Segundo a filosofia cartesiana, tudo poderia ser explicado através da razão, pois a forma mais segura de se chegar ao conhecimento era através da mesma. O filósofo determina a dúvida, e da máxima incerteza surge a primeira certeza: "se duvido, penso", levando ao cogito: "penso, logo existo" (DESCARTES, 1996, p. 92). Tomando como ponto de partida para o conhecimento verdadeiro o sujeito que duvida, porque a ação de duvidar implicaria em um pensamento, a loucura encontraria uma barreira para estabelecer qualquer relação com a verdade, sendo colocada fora do contexto da razão. Segundo Descartes, a loucura nunca teria espaço se o homem se dedicasse à busca incessante do verdadeiro. Foucault afirmava que, a partir deste raciocínio, o controle sobre a loucura se realizaria através da prática da razão (FRAYZE-PEREIRA, 1982).

Nesse percurso, observa-se que a loucura é concebida de diferentes formas e são os grupos sociais que a determinam, segundo o contexto no qual estão inseridos. A sociedade ocidental, moderna, exclui o diferente e reprime a diversidade diante da ordenação e do estabelecimento de atitudes e comportamentos padronizados, os quais são estruturados pela razão. Assim, na história da loucura, encontram-se concepções diferentes, seja no sentido de anormalidade, normalidade, doença ou divino.

Frente às questões que envolvem o conceito de anormalidade/normalidade psíquica, Mário Pedrosa afirmava que esses termos se encontrariam sob o domínio da ciência quantitativa, não prevalecendo no domínio da arte (apud ARANTES, 1996). Em sua opinião, os mecanismos da criação artística tiram forças do inconsciente, o que não seria totalmente diferente nos loucos, tornando impossível distinguir a obra de doentes mentais da de artistas tidos como normais.

\section{Arte bruta}

Neste debate acerca da relação entre arte e loucura, destaca-se, na França, o artista plástico Jean Dubuffet. Não podemos perder de vista a sintonia e a simultaneidade do debate entre Jean Dubuffet e Mário Pedrosa. Na década de 40, Dubuffet definiu a produção surgida de um caráter espontâneo e inventivo, de "arte bruta" ${ }^{10}$. Para ele, os seus autores são pessoas isentas de uma cultura artística, e por não seguirem normas, nem valores coletivos, as suas obras, sem influência de qualquer tradição, utilizam-se de técnicas, procedimentos e materiais singulares.

Ainda que muitas obras que deram origem à Coleção de Arte Bruta (Lausanne/Suíça) tenham saído de hospitais psiquiátricos, arte bruta não é sinônimo de arte psicopatológica. Não há, para Dubuffet, nenhuma característica de linguagem que possibilite distinguir as produções dos doentes mentais das obras dos indivíduos integrados à vida social. Logo, a condição de psicótico não comprova nem compromete o valor estético da produção. Como essa criação, não polida e não refinada, é impermeável a normas pré-estabelecidas, cada artista possui suas peculiaridades. Os conceitos de anormalidade e normalidade desaparecem frente a esses universos espontâneos e criativos.

As ligações que Jean Dubuffet estabeleceu com artistas, escritores e psiquiatras da Suíça, em grande parte, explicam a sua decisão de procurar, neste país, uma cidade para sediar a Coleção de Arte Bruta. A cidade escolhida foi Lausanne e a Coleção foi inaugurada, oficialmente, em 26 de fevereiro de

${ }^{10} \mathrm{O}$ termo apareceu mais precisamente em 1945, designando uma forma de criação artística, a qual já existia antes de sua definição e legitimação. 
1976. Dubuffet teve contato permanente com essa Coleção, contribuindo, até a sua morte, com o seu enriquecimento (THÉVOZ, 2001).

Alguns artistas da arte "bruta" eram adeptos do espiritismo: Raphaël Lonné, Augustin Lesage, Jeanne Tripier, Joseph Moindre e Jeanne Ruffié, os quais afirmavam que não eram os autores de suas obras, mas que as realizavam em estado de mediunidade. Neste sentido, surge um debate de ordem social. O espiritismo desenvolveu-se na Europa e nos Estados Unidos, na metade do século XIX, como resposta simbólica dos indivíduos retirados do seu contexto social, pelo êxodo rural, ao longo do desenvolvimento industrial. Neste período de crise, despontou a necessidade de uma revalorização das questões espirituais. Ao contrário de outras religiões, o espiritismo aproximou-se da magia e dos rituais de um xamã (THÉVOZ, 2001). Entretanto, um dos artistas, Raphaël Lonné, no fim de sua vida, distanciou-se da arte "bruta" e declarou que o caráter mediúnico de sua produção era apenas um pretexto para que os seus desenhos fossem legitimados.

Os criadores como: Alöise Wey, Gaston Teuscher, Hans Krüsi e outros descobriram a pintura, a modelagem ou qualquer outra forma de expressão plástica, no fim de suas vidas. Krüsi, por exemplo, começou a desenhar com cinqüenta e cinco anos de idade. Ele representava os camponeses, o trabalho, os animais, especialmente as vacas. Suas figuras são vivas, sugestivas e a sua preferência pela materialidade bruta o difere dos artistas naïs (THÉVOZ, 2001). Dessa forma, percebe-se que a arte bruta é realizada por indivíduos adultos, que, geralmente, começam a produzir depois de terem sofrido um trauma.

Quando entram em questão assuntos referentes à arte bruta, é relevante que se faça algumas distinções, primeiramente, diferenciando-se a arte bruta da arte naïve ${ }^{11}$. Antes de fazer essa diferenciação, é preciso

11 Arte, na língua portuguesa, é um termo de gênero feminino, enquanto art, em língua francesa, é um termo masculino, situar a arte naïve no tempo e no espaço. O termo surgiu na França, na segunda metade do século XIX, ao lado de outras correntes artísticas, para designar, a princípio, a obra do pintor Henri Rousseau. Os artistas naïfs ou ingênuos - próprio significado do termo - são autodidatas e se expressam de modo espontâneo, independente dos movimentos vigentes. Geralmente, eles pintam cenas da vida cotidiana, as festas populares, a religiosidade. A arte naïve não é um estilo, por isso, os artistas são bem diferentes entre si, cada um com a sua particularidade. É importante comentar que essa arte surgiu dentro de um contexto favorável ao seu reconhecimento. $\mathrm{Na}$ Europa, a arte naïve apareceu em meio à crise da cultura européia e à valorização do que era simples, ingênuo e "primitivo"; no Brasil, ela apareceu com o modernismo, como uma busca da identidade nacional. Embora os artistas naïfs não tenham uma cultura artística e não sigam regras estabelecidas, utilizam-se de suportes tradicionais, como a pintura a óleo, e têm o desejo de ser aceitos, reconhecidos e valorizados pela sociedade e pela arte oficial. Neste ponto, os naïfs diferem-se dos artistas "brutos". Nesses últimos, não se encontra a vontade de reconhecimento pelo público em geral, pois têm total liberdade quanto ao condicionamento social e não emprestam, da tradição, suas técnicas ou os seus temas. Os suportes utilizados não se restringem à pintura, encontrando, também, modelagens, bordados, colagens e outros. Assim, pode ser explicada a diferença entre a arte "bruta" e a arte naïve, as quais, embora se identifiquem em alguns aspectos, em outros divergem.

Segundo Thévoz (2001), uma outra distinção, mas, ao mesmo tempo, aproximação possível, acontece entre a arte "bruta" e arte infantil. As crianças, assim como os artistas "brutos", exprimemse espontaneamente, sem se preocuparem com critérios, técnicas ou regras. No entanto, a educação escolar e familiar introduz, nas crianças, normas de conduta, fundadas em um pensamento racional.

sendo assim, as escritas apresentam-se, respectivamente, como: Arte Naïve e Art Naïf. 
Os artistas "brutos", porém, escapariam dessas tendências infantis, no que se refere à intervenção da cultura, traçando livremente o seu percurso. Dubuffet almejava que a pintura recomeçasse do ponto zero, ignorando a existência de museus, galerias e comércio de arte. Ele acreditava que a arte bruta opõe-se à arte cultural e que o sistema elitista não estimula a criatividade, pelo contrário, tem o efeito de asfixiar e intimidar as manifestações (THÉVOZ, 2001). Assim, os artistas "brutos" com grande liberdade técnica e a utilização de diversos materiais, por nenhum momento se deixam influenciar pelo condicionamento imposto pela sociedade.

A sintonia entre Mário Pedrosa e Jean Dubuffet é bem perceptível, pois ambos acreditavam que o impulso criativo seria encontrado em todo ser humano e, independentemente de conhecimentos específicos ou da cultura artística, todos estavam aptos a se expressar. Ambos também protestaram contra a idéia de uma arte psicopatológica, acreditando que seria um erro concluir que as obras de doentes mentais fossem justificadas por um atributo de ordem patológica, com isso, a barreira entre arte e loucura passou a ser combatida. Independente da classificação: "virgem" ou "bruta" essas produções, consideradas espontâneas, eram defendidas por Pedrosa e Dubuffet.

\section{Produção plástica de pacientes psiquiátricos diante da crítica}

$\mathrm{Na}$ tentativa de interpretar e analisar as produções plásticas de doentes mentais, tendo em vista a expressão de cada indivíduo, destacam-se, na Europa, os estudos de alguns médicos e críticos de arte, como: Hans Prinzhorn, Marcel Réja, Walter Morgenthaler, dentre outros. Réja, iniciando essas pesquisas com o seu livro L'art chez les fous (A arte dos loucos), modificou o percurso da compreensão da obras dos alienados, convergindo para uma valorização dessa expressão. De maneira geral, os psiquiatras brasileiros interessaram-se menos pela produção plástica de doentes mentais do que os críticos de arte.

Sobre o reconhecimento ou não do valor artístico dessas obras, foi criado um debate, na imprensa, entre Mário Pedrosa e Quirino Campofiorito. Segundo este último (1949), as produções dessas infelizes criaturas eram medíocres demonstrações artísticas, que traziam as fraquezas de obras casuais e improvisações inconsistentes. Essas obras, para ele, não poderiam ser consideradas como arte, pois eram deficientes de razão e inteligência, sendo que os doentes mentais as produziam apenas por uma necessidade terapêutica. $\mathrm{Na}$ sua visão, a única validade, frente a essa questão, era o resultado positivo do tratamento terapêutico. Assim, Quirino Campofiorito acreditava que a arte era, simplesmente, um estímulo para a pesquisa científica.

Em contrapartida, Mário Pedrosa defendeu e reconheceu o valor estético da produção plástica dos pacientes do Centro Psiquiátrico Pedro II, valorizando toda aquela expressividade e espontaneidade. Para ele, essas produções formam, em si, verdadeiras obras de arte. Com isso, observa-se que as produções artísticas dos doentes mentais não encontraram aceitação geral e que o público, envolvido pelo conservadorismo e pelo condicionamento de padrões estabelecidos, tinha dificuldade de reconhecer e validar esse tipo de expressão.

Pedrosa, quando analisa as obras dos pacientes do Centro Psiquiátrico Pedro II, discute questões referentes aos impulsos interiores desses sujeitos criadores. A idéia de uma realidade interna remetenos ao artista moderno, Wassili Kandinsky. Ele acreditava que o impulso interior conseguia forças para criar, no espírito humano, uma nova característica, a qual pulsaria dentro do ser, buscando uma forma material (CHIPP, 1996). Toda a forma, segundo ele, seria uma expressão exterior de um conteúdo interior. Na tentativa de relacionar os elementos internos e externos na ordenação de obras de arte, Kandinsky afirmava que uma obra era 
bela quando conseguia conciliar os fatores internos e externos. Assim, é perceptível a sua valorização da interioridade do indivíduo, concebendo a forma através de uma força interior, nascida de uma necessidade espiritual ${ }^{12}$, na qual, a intuição seria responsável por impulsionar a criação. É importante ressaltar, também, que Kandinsky compreendia a comunicação estética como uma comunicação intersubjetiva, ou seja, entre um sujeito e outro, sem a mediação da natureza ou do objeto.

Outro artista que comunga algumas idéias de Kandinsky, principalmente no que diz respeito a essa questão de uma comunicação intersubjetiva, é Paul Klee. Para ele, essa operação também se concretizaria de maneira intersubjetiva. A obra deixou de ser modelo, produto acabado ou finalizado, para ser estímulo, ponto de partida. Segundo Klee, a arte não reproduziria o visível, mas tornaria visível (ARGAN, 2004). Assim, a intenção dele não era representar ou copiar o mundo real, mas visualizar uma realidade que se encontra além do mundo visível. A arte das crianças e dos doentes mentais interessou Paul Klee, pelo caráter espontâneo que emerge da necessidade interna. Encontra-se, desse modo, uma similaridade, não só entre a arte moderna e a produção dos psicóticos, mas, também, entre as idéias de Kandinsky e Klee e as de Mário Pedrosa, no que diz respeito às concepções de criação e de ímpeto interno.

Os artistas do museu de imagens do inconsciente na visão de Mário Pedrosa

Mário Pedrosa, na década de 40, dedicou parte de seu trabalho crítico a alguns artistas do Museu de Imagens do Inconsciente - Engenho de Dentro - e dentre eles se destacam: Emygdio, Fernando, Raphael, Adelina, Isaac e Carlos. Para melhor compreendermos as idéias de Pedrosa, faz-se

${ }^{12}$ Embora se encontre uma sintonia entre Kandinsky e Pedrosa, principalmente no que diz respeito à idéia de exteriorização de um conteúdo interior, neste ponto suas idéias diferem um pouco, pois, para o crítico, a obra não seria regida por uma via espiritual. necessário reproduzir seu discurso crítico sobre cada um destes artistas.

Carlos, de acordo com o crítico, é o autor de uma arte límpida, e a sua criação é tomada por uma idealidade mágica, em que a simetria e o espaço são elementos que predominam. Pedrosa (1980) acreditava que através da liberdade da composição, Carlos fazia recuar e avançar os planos, seguindo uma geometria secreta, pessoal, sempre numa relação espacial-mítica. Ele utilizava cores chapadas e ralas para assim preencher os espaços e ordenar os planos. As produções de Carlos estão fora do tempo ou em um espaço oniricamente deslocado. Um determinado dia, ele observou o sol incidir sobre o espelho de seu quarto e o brilho extraordinário o deslumbrou. Assim, surgiu, diante de Carlos, uma visão cósmica, a qual ele denominou: "O Planetário de Deus" (Figura 1). Este foi o ponto decisivo para o seu internamento, em 1939, no Hospital da Praia Vermelha. Só em 1946 é que Carlos começou a freqüentar as oficinas da Seção de Terapêutica Ocupacional, no Engenho de Dentro. Carlos, segundo o crítico, não foi apenas um artista, mas um sábio, pois assumiu um papel importante na condução do mundo e na elevação dos homens.

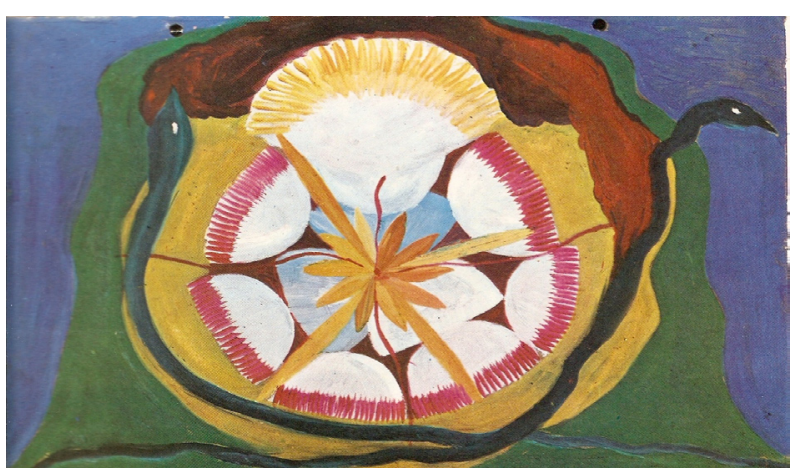

Figura 1. Óleo sobre cartolina, 55 X $37 \mathrm{~cm}, 1947$.

Para Pedrosa (1980), Fernando, ao contrário de Carlos, era um artista sem temática transcendente. A sua mãe era costureira e sempre o levava consigo quando ia para as casas dos clientes. Quando 
Fernando foi internado no Engenho de Dentro, a sua produção foi um verdadeiro registro de tudo que reteve. Registro, pelo qual se tem uma idéia clara do quanto impressionaram, a imaginação infantil, as casas por onde passou quando acompanhava a mãe. Os objetos, as cortinas vermelhas, as mesas com as naturezas mais exuberantes da pintura brasileira, os cômodos das casas, enfim, uma série de metáforas plásticas de sua vasta produção (Figura 2). Pedrosa comentava que todo o objeto o atraía, toda a matéria o prendia, todo o êxito o fascinava e que seus temas de casas oníricas e de paisagens do seu cotidiano eram, algumas vezes, transformados em construções abstratas. O artista sempre criava a partir de temas da infância, como os espaços interiores das salas de sua imaginação. Possuía grande interesse pela textura das matérias; as plantas o atraiam pelo brilho de suas cores e os objetos, pelos pequenos detalhes. Assim, Fernando foi tido como um novo e autêntico pintor.

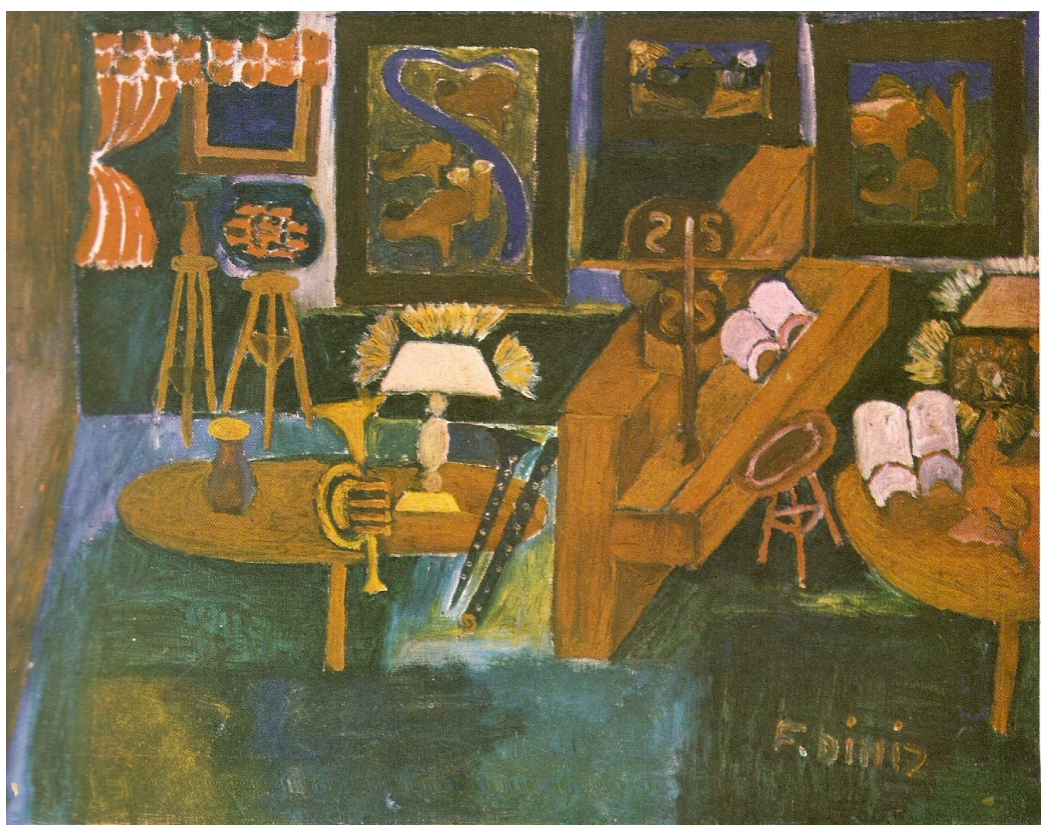

Figura 2. Óleo sobre tela, 68 X 48 cm, 1953.

Emygdio produziu, aproximadamente, três mil obras e, em oposição a Carlos e Fernando, era cuidadoso no gesto e na pincelada. Construía o seu mundo pela cor, com contrastes cromáticos vibrantes e violentos. Pedrosa (1980) afirmava que suas paisagens não copiavam a realidade, eram apenas formas tiradas do local e acrescidas de elementos imaginários. Por essa independência em relação ao modelo, acreditava-se que ele conseguia ordenar a riqueza da sua imaginação plástica e da sua fantasia, dentro de telas, geralmente, compostas com muitos elementos. Cobria o quadro com várias camadas de tinta e, nessa superposição de cores e planos, os objetivos reais uniam-se às lembranças do passado, estas sempre ligadas ao lar e às velhas casas suburbanas de sua infância. Em $O$ Municipal (Figura 3), uma de suas obras, os fatores da realidade foram apreendidos e integrados ao vigor da imaginação criadora. $\mathrm{O}$ crítico acreditava que Emygdio foi o primeiro artista que introduziu, na paisagem, o mistério, o eterno, isto é, o início do mito, descobrindo, portanto, o espírito do lugar; quanto à sua relação com o tempo e o espaço, costumava deslocar os objetos do seu lugar natural, criando uma atmosfera densa de vida interior, em uma unidade de cor fantástica. 


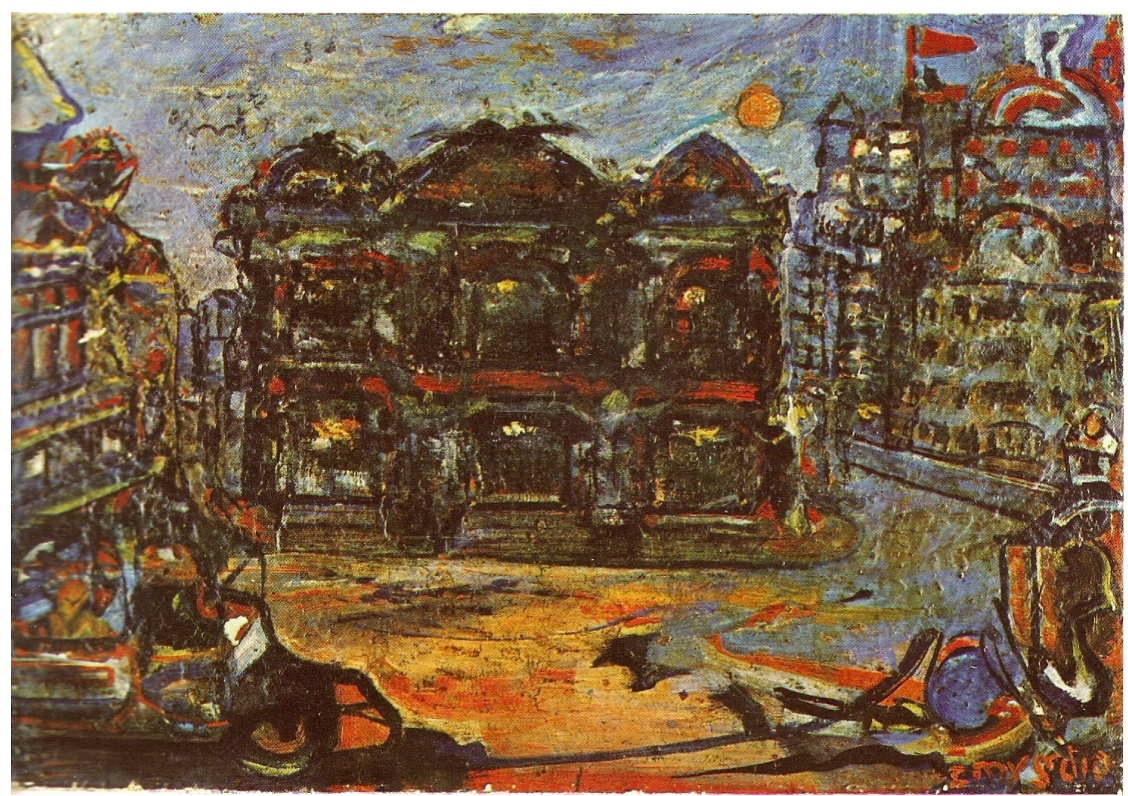

Figura 3. Óleo sobre tela, 120 X 97 cm, 1949.

Isaac é definido por Pedrosa como "uma pessoa que reduzia tudo ao contato interno" (1980, p. 142), sem interferência do mundo exterior. Dentre os vários temas que apareciam em sua obra, sobressaia a figura da mulher, sob diferentes formas (Figura 4). Sua expressão variava, constantemente, em um trânsito entre a figuração e a abstração. Suas paisagens alternam-se entre zonas de cores tranqüilas e entre zonas de cores que se agitam de maneira rápida. Estas alternações produziam, segundo Pedrosa, uma composição análoga às forças da natureza, pois estas seriam semelhantes às da natureza interna do pintor, que eram transformadas em imagens visíveis.

O caso de Raphael é um pouco diferente dos outros. Ele entrou, aos treze anos, no Liceu Literário Português, onde estudou desenho acadêmico. Todavia, este artista, segundo Mário Pedrosa (1980), construiu um mundo imaginário diferente, no qual, as normas formais e as técnicas que tinham sido apreendidas no Liceu tornaram-se impróprias e tenderam a desaparecer, dando lugar a uma expressão plástica pura e singular. Numa busca pelo estabelecimento de um equilíbrio entre a tensão interior e o estímulo exterior, Raphael tentava transformar a percepção em imagem e forma. Por meio de um impulso criador, traçava os planos e as linhas de suas obras. Vale ressaltar que, quando tratava das produções de Raphael e de Emygdio, Pedrosa as definia não como cópia do mundo real, mas como uma composição que unia os elementos externos ao ímpeto interior. É recorrente, na fala do crítico, a utilização do termo "autêntico", quando se refere às formas ou às produções desses artistas. Para reforçar essa questão, ele declarava que o segredo do desenho de Raphael encontrava-se na característica rítmica de sua forma autêntica, a qual proporcionava vida, não só às obras artísticas, mas, também, a tudo que possuía existência no mundo (Figura 5). 


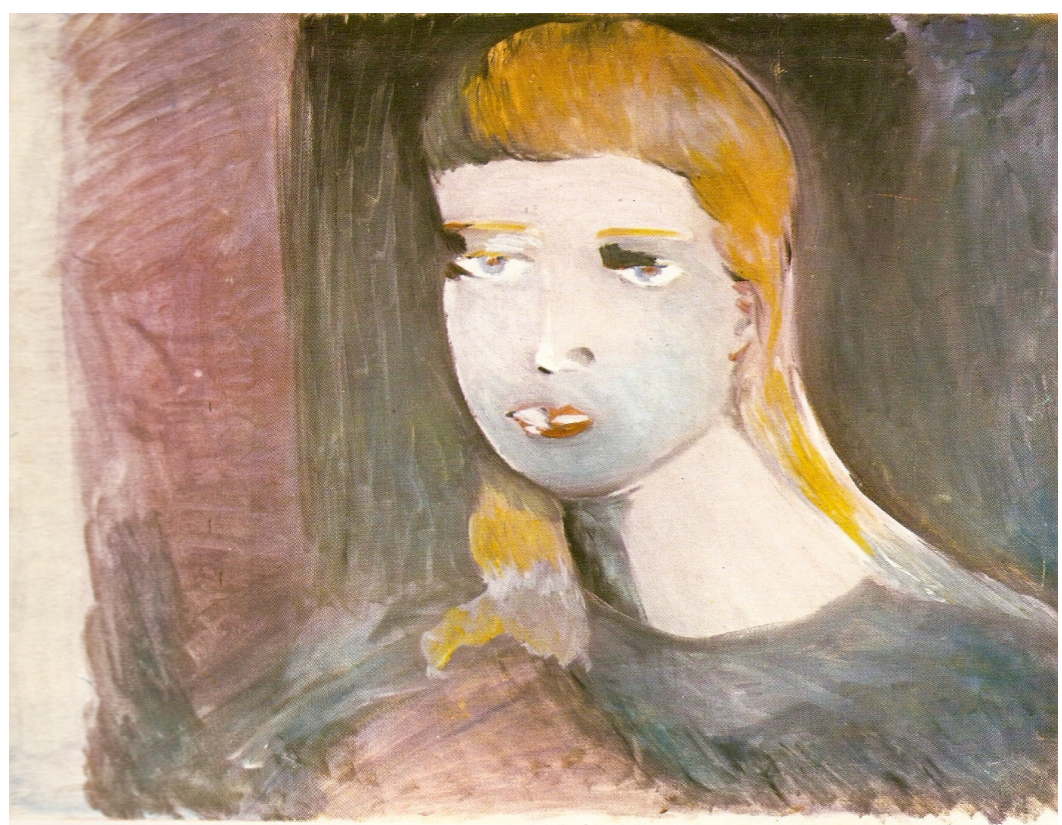

Figura 4. Óleo sobre tela, 61 X 50 cm, 1956.

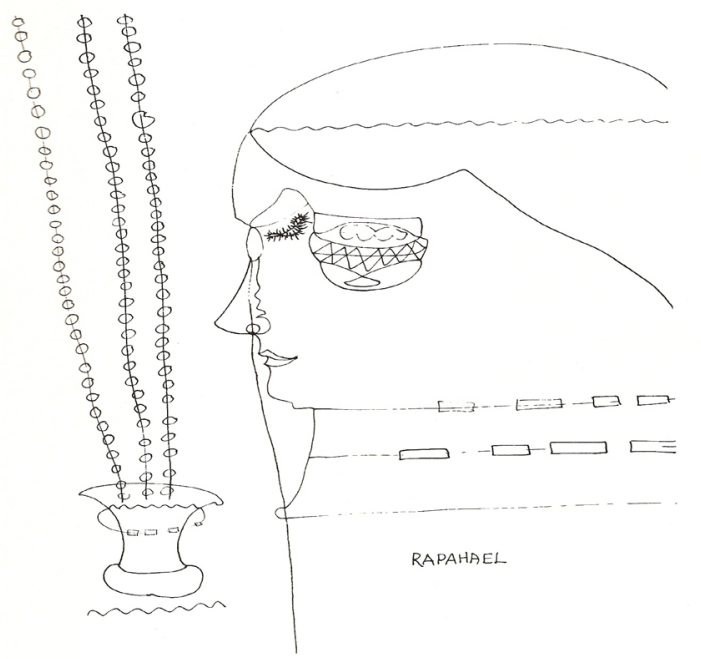

Figura 5. Nanquim sobre papel, 35 X $27 \mathrm{~cm}, 1949$.

Adelina era uma paciente que apresentava comportamento agressivo; Mário Pedrosa (1980) acreditava que tudo, em sua obra, era elementar, rude e primordial. Primeiramente, ela dedicou-se a modelar formas, que, segundo o crítico, encontravam um paralelo com as obras do período Neolítico. O seu desenho, assim como, as suas modelagens eram classificados como brutais, numa simplificação que transparecia somente a expressão simbólica. A artista não seguia nenhuma regra pré-estabelecida, obedecendo simplesmente ao seu impulso interno. Com o passar do tempo, sofreu uma transformação moral, psíquica e artística. Assim, os seus conflitos e toda aquela agressividade foram desaparecendo. Isso foi perceptível em suas novas produções: imagens líricas e dramáticas, que enfatizam o amor entre o homem e a mulher (Figura 6) ${ }^{13}$.

${ }^{13}$ Todas as imagens foram retiradas do catálogo Museu de Imagens do Inconsciente. Museu de Imagens do Inconsciente. Coleção Museu Brasileiros- 2. Rio de Janeiro, 1980. 


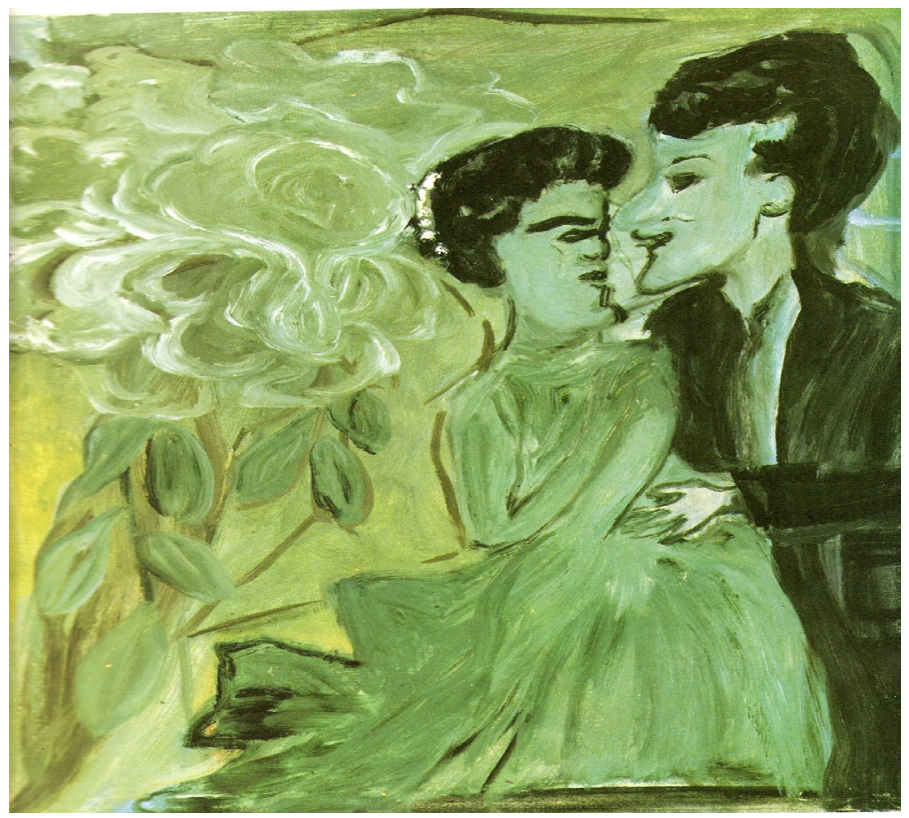

Figura 6. Óleo sobre tela, 51 X $45 \mathrm{~cm}, 1969$.

As produções plásticas dessas pessoas estavam fora de qualquer condicionamento artístico e eram elaboradas de modo independente, tanto do ponto de vista da forma como do material e da técnica. Assim, Pedrosa descrevia cada um desses artistas em universos criativos diferentes, espontâneos.

Para melhor compreendermos o pensamento de Mário Pedrosa, é necessário analisar, mais profundamente, os argumentos de sua crítica em relação às "imagens do inconsciente". É perceptível que, ao descrever esses indivíduos, Pedrosa defendia e acreditava que as produções deles eram totalmente pessoais, que partiam de combinações originais, que não seguiam padrões culturais préestabelecidos e que a única ordem obedecida seria a do impulso interior. Se essas produções não eram ditadas por regras e normas, conseqüentemente, o crítico sustentava a idéia de serem obras legítimas e puras.

Na fala de Pedrosa, salientam-se termos como: puro, intacto, instintivo, interioridade e, através deles, observamos a presença de uma visão romântica diante de tais produções. Essa questão torna-se mais compreensível quando se pensa nas características do movimento romântico.
O Romantismo voltou suas pesquisas para as questões do próprio indivíduo, colocando a expressão individual e a imaginação em um patamar superior ao da razão. O século XVIII, época do Iluminismo, foi marcado pela confiança ilimitada na razão, na objetividade e na lógica. A razão possibilitaria o progresso e a melhoria do homem, tornando-o equilibrado. Entretanto, o Romantismo alterou esse ponto de vista e elegeu como princípio, a subjetividade e a sensibilidade. Opunha-se aos cânones da arte e da literatura, e pregava a substituição destes pela exteriorização espontânea dos conteúdos interiores. Nascia, assim, uma outra concepção de gênio, o gênio orgânico, aquele que devia, tal como uma planta, desenvolver-se livremente, sem a interferência da educação formal; a criação seria, então, análoga à de um organismo, pois se desenvolveria de maneira espontânea, devido à sua própria natureza (SUZUKI, 1998). Sua obra não seguiria normas e não teria a pretensão de imitar, sendo determinada, apenas, pelas necessidades interiores. Com isso, pensando nas questões acerca de um talento inato, de expressões espontâneas e da originalidade, o gênio tornou-se, no romantismo, o ponto central entre o impulso interior e o mundo exterior. 
Em relação a essa concepção de gênio, cita-se outro filósofo: Jean-Jacques Rousseau. Precursor de algumas idéias do romantismo, este filósofo valorizava o sentimento em detrimento da razão, assim, o indivíduo deveria voltar-se para si mesmo, no sentido de capturar os sentimentos interiores, os quais ele denominava de natureza (GUINSBURG, 2005). A expressão dessa natureza estaria atrelada à genialidade. Rousseau buscava um homem natural, o "bom selvagem" e, na sua visão, o progresso corrompia a sociedade. Sendo assim, procurava uma natureza pura, primitiva e, como se poderia dizer, estava em busca de um paraíso perdido. Encontramos em Rousseau umas das fontes do romantismo, no que se refere ao interesse pelo exótico, pela natureza em seu estado "bruto" e pela fuga da realidade.

O historiador da arte, Giulio Carlo Argan (2004), afirmava que o classicismo e o romantismo seriam duas formas diferentes de idealizar. Segundo ele, no romantismo, o sentimento era individualizado, possibilitando, assim, a ligação entre a natureza e o indivíduo. Oposto à ordem, à moral e à racionalidade do neoclassicismo, o romantismo introduz a desordem, o caos criativo, voltando-se para a interioridade humana.

Quando observamos as características do Romantismo, consequentemente, entendemos melhor a influência deste sobre Mário Pedrosa e a visão que este tinha a respeito da produção plástica dos pacientes do Centro Psiquiátrico Pedro II. Embasado na idéia de subjetividade, imaginação criadora e genialidade orgânica, Pedrosa interpretava a produção plástica dos internos do Engenho de Dentro como expressão espontânea, manifestada por seres mais puros, simples e "virgens". A genialidade seria um estado de infância e a inspiração tendia a identificar-se com as forças espontâneas, vitais e inconscientes. Para o crítico (1947), as imagens nascidas desta condição de virgindade, eram harmoniosas, sedutoras e dramáticas. Observamos, portanto, que a crítica de Pedrosa está embasada por uma concepção idealizada e romântica.
Após ter salientado a similaridade do pensamento de Mário Pedrosa com as características do romantismo, torna-se necessário comentar uma frase do crítico, sobre a exposição nove artistas do Engenho de Dentro, a qual aconteceu na Câmara dos vereadores, patrocinada pelo Museu de Arte Moderna de São Paulo.

Era difícil dizer que aquelas produções eram de doentes mentais. Pode-se evidentemente, encontrar nelas, como aliás em toda obra, em toda criação humana, manifestações provenientes de almas conturbadas, perene ou momentaneamente, de impulsos interiores que a técnica psiquiátrica geralmenteidentifica comopertencentes à constituição psíquica do esquizofrênico. Tais sintomas, porém, também são reconhecíveis, nos tipos considerados normais (PEDROSA, 1979, p. 106).

Notranscorrer deste discurso, Pedrosa reitera suas idéias acerca das questões referentes à anormalidade e normalidade psíquica, das quais, em sua opinião, eram termos da ciência quantitativa e que não prevaleciam no domínio da arte. Ao comentar sobre a dificuldade de se afirmar que tais produções eram de doentes mentais, o crítico, na verdade, está querendo nos mostrar a impossibilidade de se distinguir as obras dos esquizofrênicos das de artistas considerados normais.

Assim, Mário Pedrosa assume uma postura de defesa em relação à expressão plástica dos doentes mentais, acreditando na pureza, espontaneidade e singularidade desses criadores.

Por fim, não podemos perder de vista que através de um contexto favorável à legitimação de formas mais "simples" e "puras", encontramos, em Pedrosa, um reconhecimento da produção plástica dos alienados. Como foi visto, teorias e conceitos contribuíram para estruturar o seu pensamento, e a sua concepção de arte "virgem", de criação e de espontaneidade; todos esses elementos encontramse estreitamente relacionados e presentes no discurso de Mário Pedrosa. 


\section{Considerações finais: a crítica da crítica de Mário Pedrosa}

"O homem, objeto do objeto de si mesmo, talvez vá terminar seu ciclo, sem saber mais onde encontrar sua essência ou sua substância”.

Mário Pedrosa

A crítica de Mário Pedrosa leva-nos a pensar questões pontuais acerca do seu discurso frente à expressão plástica dos doentes mentais. Ao defender essas produções, Pedrosa apresentava uma visão pautada nos ideais românticos. É importante lembrar que o crítico prezava a exteriorização espontânea de conteúdos internos e acreditava que aquelas obras eram instintivas, puras e inconscientes.

Ao analisar a obra de Carlos, um dos pacientes do Centro Psiquiátrico Pedro II, Pedrosa acreditava que a criação desse artista era tomada por uma idealidade mágica. Nesse ponto, surge uma questão: esta idealidade mágica emanava de Carlos ou da própria visão do crítico diante das produções? Esta é uma discussão que fica em aberto. Entretanto, se pensarmos que Pedrosa apresentava-se envolvido com demanda romântica, esse fato, pode falar muito mais sobre a concepção idealizada do crítico do que sobre o próprio artista.

Baseado na idéia de uma realidade interna ou de um impulso interior, frequentemente, constará de sua fala, o termo autêntico. Isso é perceptível não só ao descrever Fernando, mas também Raphael e tantos outros internos. Emygdio, assim como Isaac, eram descritos através de uma voraz natureza interior. "Criadores originais", "espontâneos" e "virgens", esta é, em síntese, a visão de Pedrosa acerca desses artistas.

A própria denominação "virgem", utilizada por Pedrosa ao se referir àqueles criadores, já implica em uma definição idealizada. Isentos de qualquer convenção acadêmica, esses artistas seriam puros e singulares. Fruto do Romantismo, a idéia de gênio orgânico também se faz presente em Mário Pedrosa.
Porém, é necessário compreendermos a importância desta defesa de uma arte virgem no contexto histórico em que ela de seu. Ao defender essas produções, Pedrosa estava, consequentemente, defendendo os seus ideais frente à política e à arte, pois não podemos perder de vista que o crítico sustentava a idéia de autonomia, tanto em relação ao sistema capitalista quanto às convenções acadêmicas. Esses artistas "virgens", na sua visão, eram totalmente independentes de convenções clássicas, e suas obras, distantes de regras pré-estabelecidas, iam ao encontro dos ideais do crítico. Defender a existência de uma arte virgem significava também afirmar que a criação não é privilégio de alguns, de uma classe social letrada, mas uma capacidade inerente ao ser humano, de suma importância, pois revela nosso impulso libertário.

Em toda a trajetória de Mário Pedrosa, percebemos uma vontade de luta, pois, para ele, a revolução seria um caminho para se alcançar a liberdade do indivíduo.

Um debate importante instaurado, não só por Pedrosa, mas também por Jean Dubuffet, foi o questionamento da idéia de uma arte psicopatológica. A condição de doente mental não comprovaria, nem comprometeria o valor artístico da produção. Para Pedrosa, no campo da arte, não prevaleciam as questões de normalidade/anormalidade psíquica, estes seriam termos da ciência quantitativa. Assim, alguns pré-conceitos referentes à produção plástica dos doentes mentais passaram a ser combatidos e o obstáculo entre arte e loucura passou a ser questionado.

Toda a crítica de Pedrosa está embasada em teorias e conceitos que o ajudaram a pensar as questões referentes à arte e ao processo de criação. Lembramos, então, da Teoria da Gestalt para a compreensão da criação artística; a manifestação de formas dos conteúdos internos dos alienados iria, segundo o crítico, ao encontro das leis dessa teoria. Não nos esqueçamos, também, da Teoria da Evolução de Darwin e da visão "romântica" 
de criação. O contexto do "primitivismo" e da valorização de formas simples e puras contribuiu para que a expressão plástica dos doentes mentais fosse legitimada. A sua crítica, portanto, apresenta sintonia e simultaneidade com as pesquisas da época.

Alinhando os seus ideais na arte e na política, acreditava que a postura frente a elas deveria ser de crítica e de militância. Assim, redefinindo o seu pensamento, percebemos a sua inquestionável importância intelectual.

\section{Referências}

AMABIS, J. M.; MARTHO, G. B. Biologia das populações: genética, evolução e ecologia. São Paulo: Moderna, 1999.

ARANTES, O. B. F. Mário Pedrosa: itinerário crítico. São Paulo: Página Aberta, 1991.

ARANTES, Otília. (org.) Política das artes - Mário Pedrosa, Textos escolhidos, São Paulo, Edusp, 1995.

ARGAN, G. C. Arte moderna. São Paulo: Companhia das Letras, 2004.

BAUDELAIRE, C. A modernidade de Baudelaire. Rio de Janeiro: Paz e Terra, 1988.

CAMPOFIORITO, Q.(1949, 04 de dezembro). Arte e Psiquiatria. O Jornal.

CAZENEUVE, J. Lucien Lévy-Bruhl: as vie, son oeuvre avec um exposé de sa philosophie. Paris: Presses Universitaires de France, 1963.

CHEVALIER, J.; GHEERBRANT, A. Dicionário de símbolos: mitos, costumes, gestos, formas, figuras, cores, números. Rio de Janeiro: José Olympio, 2001.

CHIPP, H. B. Teorias da arte moderna. São Paulo: Martins Fontes, 1996.

DANTAS, M. Os filhos de Dionísio: arte e loucura no pensamento de Jean Dubuffet. In: SANTOS, V. O trágico e seus rastros. Londrina: Eduel, 2004. p. 133-154.

DESCARTES, R. Discurso do Método: As Paixões da Alma, Meditações, Objeções e Respostas. São Paulo: Nova Cultural, 1996.

FERRAZ, M. H. C. T. Arte e loucura: limites do imprevisível. São Paulo: Lemos, 1998.
FRAYZE-PEREIRA, J. O que é loucura. São Paulo. Brasiliense, 1994.

FREIRE-MAIA, N. Teoria da evolução: de Darwin à Teoria Sintética. São Paulo: Edusp, 1988.

GADAMER, H.; VOGLER, P. Nova antropologia: o homem em sua existência biológica, social e cultura. São Paulo: Edusp, 1977.

GOLDMAN, M. Razão e diferença: afetividade, racionalidade e relativismo no pensamento de LévyBruhl. Rio de Janeiro: Grypho, 1994.

GUILlaume, P. Psicologia da forma. São Paulo: Companhia Editora Nacional, 1966.

GUINSBURG, J. O Romantismo. São Paulo: Perspectiva, 2005.

KANDINSKY, W. De lo espiritual en el arte. Barcelona: Labor, 1972.

LEVI-STRAUSS, C. O pensamento selvagem. São Paulo: Companhia Editora Nacional, 1970.

LÉVY-BRUHL, L. L'ame primitive. Paris: Quadriage, 1963.

LOUREIRO, I. Mário Pedrosa e o socialismo democrático. In: In: Amaral, A. (org.). Mario Pedrosa e o Brasil. São Paulo: Fundação Perseu Abramo, 2001. p. 132.

OSTROWER, F. Criatividade e processos de criação. Rio de Janeiro: Vozes, 1987.

MODERNO, J. R. Entrevista com Mário Pedrosa. In: Arte e Politica no Brasil. Rio de Janeiro: Pallas, 1984. p. 27-37.

NETO, J. C. M. (Org.). Mario Pedrosa e o Brasil. São Paulo: Fundação Perseu Abramo, 2001.

PEDROSA, M.; ARANTES, O. (Org.). Acadêmicos e modernos. São Paulo: Edusp, 2004.

1996.

. Forma e percepção estética. São Paulo: Edusp, . Política das artes. São Paulo: Edusp, 1995.

PEDROSA, M. Arte/Forma e personalidade. São Paulo: Kairós, 1979.

PEDROSA, M. Arte, Necessidade Vital. Correio da Manhã, Rio de Janeiro, 7 dez. 1947.

Mundo, homem arte em crise. São Paulo: Perspectiva, 1986.

. Sobre o PT. 2. ed. São Paulo: Ched, 1980. 
PERRY, Gill. O primitivismo e o "moderno". In: HARRISON, Charles et al. Primitivismo, cubismo e abstração: começo do século XX. São Paulo: Cosac \& Naify, 1998. p. 3-85.

Silveira N. O Mundo das imagens. São Paulo: Ática; 2001.

SILVEIRA, N. Imagens do inconsciente. 4. ed. Brasília: Alhambra, 1981.

. O mundo das imagens. São Paulo: Ática, 1992. .. Museu de Imagens do Inconsciente. In: PEDROSA, Mário (Org.). Museu de Imagens do Inconsciente. Rio de Janeiro: Funarte/Instituto Nacional de Artes Plásticas, 1980.
SCHULTZ, D.; SCHULTZ, S. História da psicologia moderna. São Paulo: Cultrix, 1981.

SCHULTZ, D.; História da psicologia moderna. São Paulo:Cultrix, 1981

SUZUKI, M. $O$ gênio romântico: crítica e história da filosofia em Friedrich Schlegel. São Paulo: Iluminuras, 1998.

THÉVOZ, Michel. Collection de l'art brut, Lausanne. Zurique/Genève: Instituit Suisse pour l'étude de l'art/ BNP Paribas Suisse, 2001.

ZANINI, Walter (apresentação geral). XVI Bienal de São Paulo - Arte Incomum, Fundação Bienal de São Paulo, São Paulo, 1981. 